CHAPTER 2

\title{
The Past, Present, and Future of Agriculture Policy in Africa
}

Ousmane Badiane, Julia Collins, and John M. Ulimwengu 
$\mathrm{n}$ the 1990s and early 2000s most studies painted a bleak picture of the economic performance of Africa south of the Sahara (SSA). For Easterly and Levine, Africa's economic history since the independence era "fits the classical definition of tragedy: potential unfulfilled, with disastrous consequences" (1997, 1). Likewise, Artadi and Sala-i-Martin (2003) later described Africa's poor growth performance as an economic tragedy, attributed to insufficient levels of education, health, and investment, as well as conflict, unfavorable geography, and inappropriate policies. The collapse of SSA economies explains the region's widespread poverty and its consequences. For example, Easterly and Levine (1997) noted that the majority of African mothers could expect to lose at least one child before age five, and that average life expectancy and daily calorie intake were far lower in SSA than in other developing regions.

This somber period of economic decline and stagnation marked a striking contrast with Africa's healthy growth performance during the 1960s and early 1970 s. Equally striking has been the strong recovery observed since the early 2000s, with considerable growth acceleration across the continent. However, African economies have not yet caught up with their growth trajectories of the 1960s (Badiane et al. 2015). The policies chosen by leaders have much to do with the dramatic changes in Africa's fortunes over the past decades and will continue to shape the continent's prospects in the decades to come. Weaknesses in agriculture-sector and macroeconomic policies have shaped the performance of African economies, which in turn stifled the capacity of countries to make the necessary growth-enhancing investments in skills, services, and infrastructure in the decades leading to and through the period of decline. Improvement in the same policies and investment decisions have made the longest sustained period of economic growth in the continent's history possible (Badiane and Makombe 2015; Conway, Badiane, and Glatzel 2019).

There have been plenty of attempts to explain the growth recovery as the result of booms in global export markets or better rainfall conditions. The weakness of such arguments is that these booms and conditions occurred in the past as well, and precisely during the very periods of economic decline. Why did economies respond this time to positive developments, and why did this response result in a two-decades-long growth spell? The reason is that improvement in policy regimes and economic governance-the sum of policies and regulatory measures that define the rules of the game and the roles of different actors, at the macroeconomic and sector levels-placed economies in a better position to boost agricultural production in response to better weather conditions and to grab opportunities in global markets in order to fuel domestic growth. The geographic spread and sustained character of the current recovery can be explained only by factors that have affected a broad range of countries, not just primary exporters, and have transcended variations in rainfall conditions across countries. These factors are primarily related to the painful and controversial reforms carried out by most African countries during the structural adjustment programs. These reforms helped reduce fiscal deficits, brought inflation under control, created room for the private sector, and cut the level of implicit taxation faced by smallholder farmers. The changes were deep and it took a while for most economies to weather them, but countries emerged strengthened and poised for a remarkable recovery (Badiane et al. 2015; Devarajan and Shetty 2010).

The above lessons are important as we look forward to the next couple of decades. A major economic policy question is how to sustain and broaden the current recovery process in order to further accelerate the pace of improvement in incomes, poverty, and hunger, and continue to enhance prosperity for all Africans. Related questions are how to build on the reforms of the past and continue to improve economic governance and agricultural sector policies. Agricultural policies are key to overall development due to the central role of agriculture in broader economic growth and transformation, which is related to strong linkages between agriculture and other sectors, among other factors (see Conway, Badiane, and Glatzel 2019). At the minimum, there is a need to maintain the positive changes of the past and avoid a return to policies that led to the lost decades of economic decline and stagnation. At best, we need to find the right mix of policies, some new, some old, that will meet the needs of rapidly modernizing agricultural value chains and transforming national economies.

Against the background just discussed, this chapter reviews changes in Africa's economic and agricultural development, and explores their origins in the types of policies pursued by leaders. It examines the strategies and economic trends of the past, in the decades since independence; discusses the innovations of the current Comprehensive Africa Agriculture Development Programme (CAADP) era; and describes future policy challenges as we approach the third decade of CAADP implementation. In the first section, we review trends over the past decades in economic growth, agricultural production and productivity, and poverty and hunger. Next, we describe the evolution of agricultural and 
macroeconomic policies in the decades since Africa's independence. The third section uses econometric analysis to link policy changes and macroeconomic management indicators to economic growth outcomes. The fourth section describes policy renewal efforts under CAADP, and the next section discusses the growing danger of policy reversal and the importance of mutual accountability processes to mitigate this risk. The sixth section discusses new and emerging policy challenges facing policymakers today, and the final section concludes with some remarks on the way forward.

\section{Long-Term Agricultural and Economic Growth Trends}

In this section we briefly describe some of the elements of Africa's growth trajectory during the decades since independence. At the broadest level, the story of Africa's economic development is, as mentioned above, marked by episodes of decline and recovery. Figure 2.1 shows average annual growth in gross domestic product (GDP) by decade for a group of 30 African countries that have complete data for all years since 1960.1 For the entire group, GDP grew at around 4 percent annually during the 1960s and 1970s, but growth decelerated sharply, to around 2 percent per year, during the 1980s and 1990s. However, growth rebounded during the 2000s, with GDP increasing at more than 5 percent per year. Growth was less robust during the 2010s, at 3.3 percent per year. Patterns of economic growth differed somewhat by region, but most regions followed the same general trajectory of healthy growth early on, very low growth during the 1980s and 1990s, and even faster growth in the 2000s.
FIGURE 2.1-ANNUAL AVERAGE PERCENTAGE GROWTH OF GDP BY DECADE, 30 AFRICAN COUNTRIES, 1960-2018

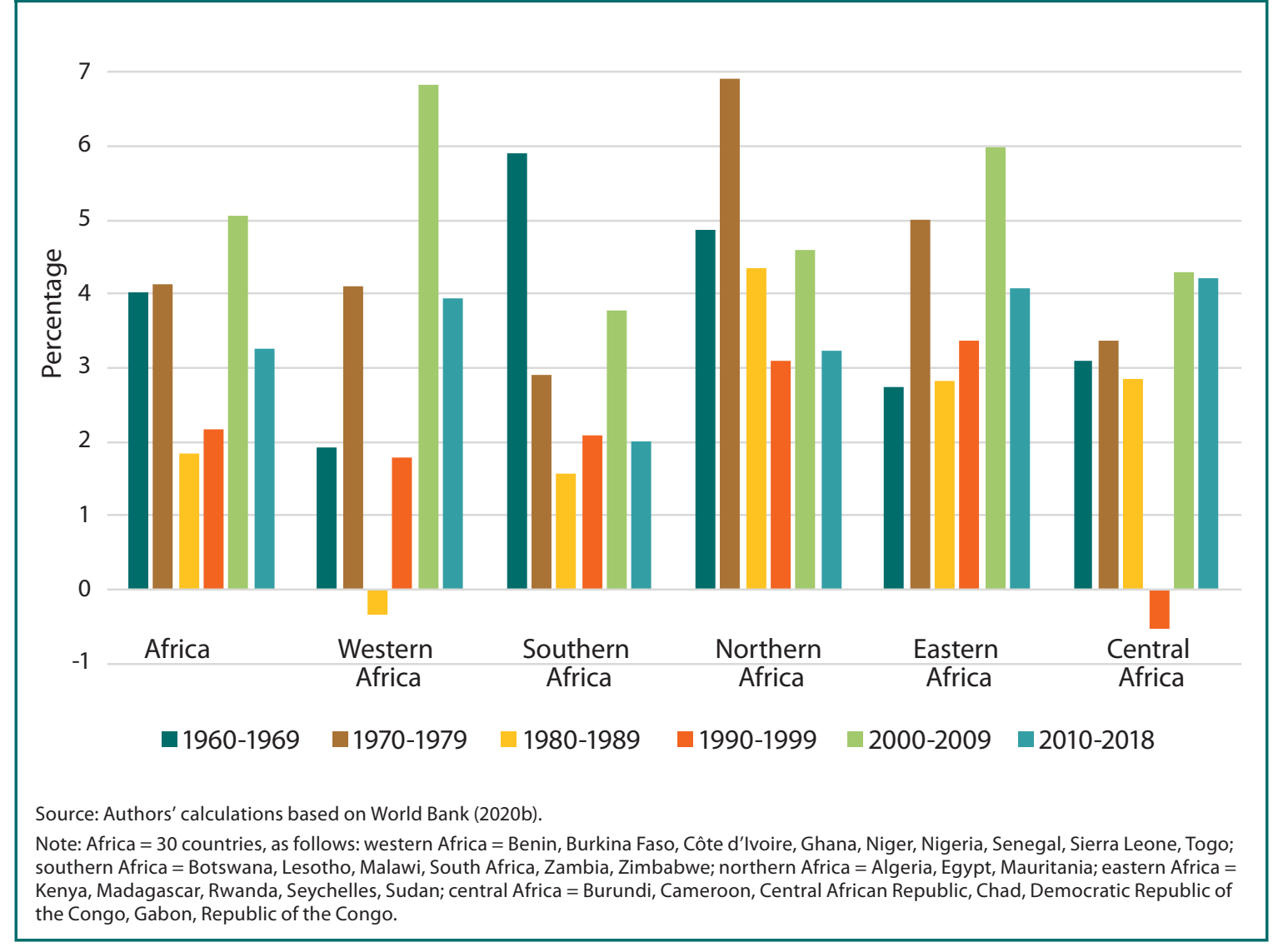

The lackluster GDP growth of the 1980s and 1990s fell below population growth, and average incomes declined each year for nearly two decades. Figure 2.2 shows the evolution of GDP per capita for the same group of 30 countries. Growth stalled in the second half of the 1970s and fell thereafter. At the bottom of the trough, in 1994, average incomes in this group of countries were

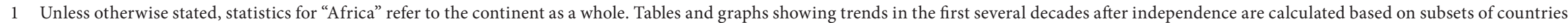
that have complete data for the time period; although results may be affected by the subset of countries to some extent, they echo findings from other literature, and we believe that they are reasonably reflective of trends on the continent as a whole. Tables and graphs covering trends during the 1980s and after are based on most African countries, unless otherwise stated. 


\section{FIGURE 2.2-GDP PER CAPITA (IN CONSTANT 2010 US DOLLARS),} AFRICA, 1960-2018

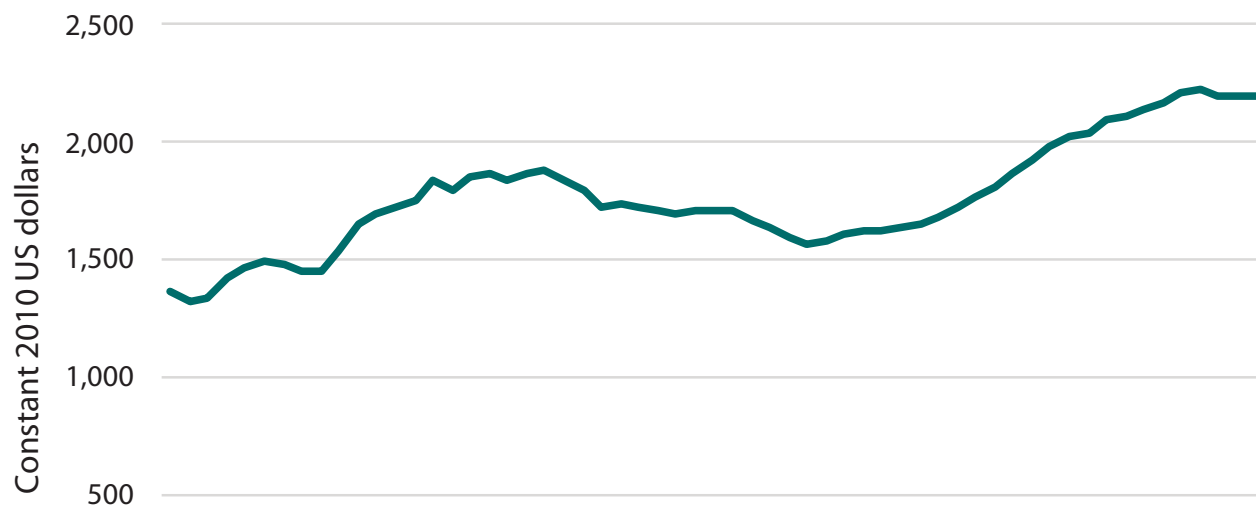

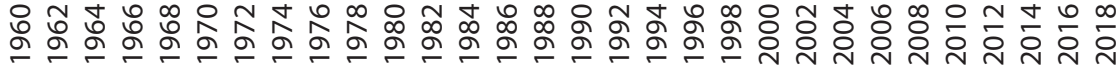

Source: Authors' calculations based on World Bank (2020b).

Note: Africa = Algeria, Benin, Botswana, Burkina Faso, Burundi, Cameroon, Central African Republic, Chad, Côte d'Ivoire, Democratic Republic of the Congo, Egypt, Gabon, Ghana, Kenya, Lesotho, Madagascar, Malawi, Mauritania, Niger, Nigeria Republic of the Congo, Rwanda, Senegal, Seychelles, Sierra Leone, South Africa, Sudan, Togo, Zambia, and Zimbabwe.
TABLE 2.1-AVERAGE ANNUAL PERCENTAGE GROWTH IN AGRICULTURAL VALUE ADDED, AFRICA, 1980-2018

\begin{tabular}{|l|c|c|c|c|}
\hline Region & $\mathbf{1 9 8 0 - 1 9 8 9}$ & $\mathbf{1 9 9 0 - 1 9 9 9}$ & $\mathbf{2 0 0 0 - 2 0 0 9}$ & $\mathbf{2 0 1 0 - 2 0 1 8}$ \\
\hline Africa & $\mathbf{4 . 1 5}$ & $\mathbf{2 . 8 1}$ & $\mathbf{5 . 1 8}$ & $\mathbf{3 . 7 0}$ \\
\hline Western Africa & 6.86 & 4.46 & 6.24 & 2.14 \\
\hline Southern Africa & 0.24 & -0.44 & 2.85 & 2.72 \\
\hline Northern Africa & 5.70 & 5.33 & 2.76 & 6.78 \\
\hline Eastern Africa & 2.44 & 2.06 & 7.81 & 6.31 \\
\hline Central Africa & 3.41 & 12.54 & 2.02 & 5.75 \\
\hline \multicolumn{5}{|l|}{ Source: Authors' calculations based on ReSAKSS (2020). } \\
\hline
\end{tabular}

TABLE 2.2-ANNUAL AVERAGE LABOR AND LAND PRODUCTIVITY GROWTH (PERCENTAGES), AFRICA, 1980-2018

\begin{tabular}{|l|c|c|c|c|}
\hline Variable & $\mathbf{1 9 8 0 - 1 9 8 9}$ & $\mathbf{1 9 9 0 - 1 9 9 9}$ & $\mathbf{2 0 0 0 - 2 0 0 9}$ & $\mathbf{2 0 1 0 - 2 0 1 8}$ \\
\hline Labor productivity & 1.33 & 0.55 & 1.82 & 2.03 \\
\hline Land productivity & 3.23 & 1.27 & 3.52 & 4.31 \\
\hline
\end{tabular}

Source: Authors' calculations based on ReSAKSS (2020).

Note: Labor and land productivity are measured as agricultural value added (in constant 2010 US dollars) per worker and per hectare, respectively. below their 1970 level. However, robust growth resumed from the mid-1990s through the mid-2010s. It is a concern that GDP per capita has remained flat for the period from 2015 to 2018. It remains to be seen whether this is a temporary setback or if the growth recovery has weakened. The long-term trends of economic decline followed by a resurgence of growth have much to do with the changing policy regimes pursued by governments, as discussed in the following section.

\section{Agricultural Production and Productivity}

Although data on agricultural output from the decades immediately following independence are limited, available data tell a similar story of stagnation and recovery (Badiane et al. 2015). Figure 2.3 shows agriculture value added per capita for a group of 16 countries with complete data from 1965 to 2018. For this group, annual value added remained around US $\$ 240$ per person for decades before increasing significantly in the late 1990s. For the larger group of African countries, the agricultural growth recovery likely began during the 1980s. As shown in Table 2.1, agriculture grew at more than 4 percent per year during the 1980s, decelerated in the 1990s, and resumed rapid growth in the 2000s of more than 5 percent per year. Similarly to overall economic growth patterns, agricultural growth in the 2010s has been positive but less robust than that of the 2000s. Agricultural growth trends show significant differences by subregion, with the low average growth rates of the 1990s driven mainly by southern and eastern Africa. The health of Africa's agricultural sectors over the decades has been strongly affected by sector governance and policy regimes (discussed in the next section).

Although in the past decades Africa's output growth has been driven by the expansion of agricultural land, land and labor productivity have been 
FIGURE 2.3-AGRICULTURAL VALUE ADDED PER CAPITA, 16 AFRICAN COUNTRIES (CONSTANT 2010 US DOLLARS), 1965-2018

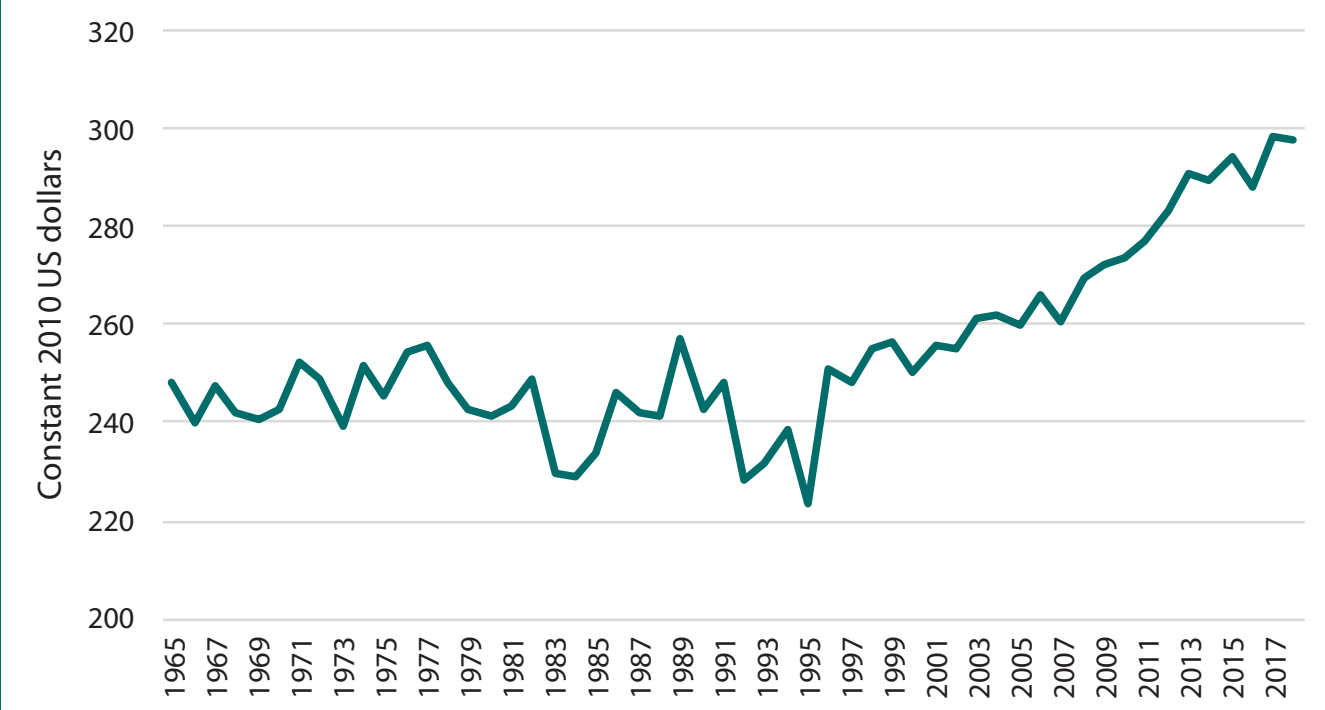

Source: Authors' calculation based on World Bank (2020b).

Note: The countries are Botswana, Burundi, Cameroon, Egypt, Kenya, Mauritania, Morocco, Republic of the Congo, Rwanda Senegal, Sierra Leone, South Africa, Sudan, Togo, Tunisia, and Zambia.

increasing since the mid-1980s. However, Benin and colleagues (2011) found that productivity growth from the mid-1980s through 2010 had served only to return productivity to its levels of the early 1960s, following sharp declines in the intervening decades. Productivity growth has continued to increase during the 2010s, exceeding that of the three preceding decades for both land and labor productivity (Table 2.2). Land productivity growth was especially high, at more than 4 percent per year.

\section{Poverty and Nutrition}

Nearly two decades of economic decline had devastating effects on Africa's overall development and population welfare. As of 1990, more than half of the population of SSA was poor according to the international poverty line of US $\$ 1.90 /$ day, and the region's poverty rate was second only to that of East Asia and the Pacific (EAP). Poverty in EAP declined rapidly thereafter, whereas in
TABLE 2.3-CHILD UNDERNUTRITION INDICATORS AND HUMAN DEVELOPMENT INDEX, ANNUAL

AVERAGE CHANGE, AFRICA, 1990-2018

\begin{tabular}{l|c|c|c|}
\hline Variable & $\mathbf{1 9 9 0 - 1 9 9 9}$ & $\mathbf{2 0 0 0 - 2 0 0 9}$ & $\mathbf{2 0 1 0 - 2 0 1 8}$ \\
\hline Stunting & -0.83 & -1.21 & -1.49 \\
\hline Wasting & -0.57 & -0.97 & -1.57 \\
\hline Underweight & -0.64 & -1.60 & -1.82 \\
\hline HDI & 0.67 & 1.28 & 0.95 \\
\hline $\begin{array}{l}\text { Source: Authors' calculations based on ReSAKSS 2020 (nutrition indicators) and UNDP } 2020 \\
\text { (HDI). }\end{array}$ \\
$\begin{array}{l}\text { Note: HDI = Human Development Index. The third period for wasting is 2010-2017; the first } \\
\text { period for HDI is 1990-2000. HDI values are population-weighted averages for 39 African } \\
\text { countries that have data starting in 1990. }\end{array}$
\end{tabular}

SSA it rose slightly, only beginning to decline with the economic recovery in the late 1990s and 2000s (World Bank 2020a).

Africa also had very high rates of undernutrition in the early 1990s: 45 percent of children younger than five were stunted, 26 percent were underweight, and 11 percent suffered from wasting in 1991. In the nearly three decades from then until 2018, all three indicators had improved significantly, but rates remained high, at 33 percent, 18 percent, and 8 percent, respectively. Although reductions in undernutrition have not been as rapid as hoped, some countries and regions have shown significant improvements, and at the continental level the declines in all three indicators have accelerated in each decade (Table 2.3). The average Human Development Index (HDI) score for Africa also improved steadily over time. The improvements in hunger and in HDI, and the accelerations of progress in the 2000s, are related both to increasing incomes and to institutional, programmatic, and policy innovations in African countries (Malabo Montpellier Panel 2017).

The erratic changes in economic and agricultural development described above, and their impacts on poverty and hunger, have many causes, including weather shocks, conflict, and changes in the global trade and financial environment. However, governments' policies are major drivers of the observed trends. In the next section, we review changes in the types of macroeconomic and agricultural policies pursued by African countries in the decades since independence, and their impacts on growth and welfare. 


\section{Evolution of Agricultural-Sector and Macroeconomic Policy Regimes}

Independence and the Struggle for Industrialization During the independence era of the 1960s, many policymakers, guided by still-forming international development theory, saw development as inextricably linked to industrialization (Bautista 1990). They pursued import-substitution industrialization (ISI) strategies, erecting import barriers in an effort to protect nascent industries from competition. Agriculture, which employed the majority of the population in most countries, was seen only as a source of resources to support industry (Badiane and Makombe 2015). Consequently, agriculture suffered significantly from industrial protection. Trade restrictions and distorted macroeconomic policies squeezed farmers in several ways, including by raising prices of imported fertilizer and equipment, and by provoking appreciations in the real exchange rate, which raised costs of nontradable goods and services, including labor. Exchange rate appreciations also caused tradable goods such as farm products-exported and import-competing crops alike-to lose competitiveness compared with foreign products (Bautista 1990). Other common elements of agricultural policies in developing countries during the ISI era included marketing controls and export taxes, which depressed agricultural producer prices, and in some cases, direct support to farmers through input subsidies or agricultural investments, which partly_but not fully-compensated for the negative effects of industrial protection and export barriers (Krueger, Schiff, and Valdés 1988; Oyejide 1986; Tshibaka 1986; Badiane and Kinteh 1994).

Agricultural marketing systems commonly included government monopolies on crop marketing, through marketing or export boards; restrictions on private commerce; and centrally determined, panterritorial and panseasonal pricing. Private traders were not allowed to participate in the marketing of agricultural products. In several countries, it was illegal to carry a bag of produce across district lines. Policies frequently favored large farmers and processors. For example, in several eastern and southern African countries, small maize mills were shut out of the formal processing sector while large mills benefited from grain price subsidies (Jayne and Jones 1997). Depressed producer prices and low levels of investment in rural infrastructure and services contributed to a growing gap in rural versus urban living standards. These policies both impoverished farmers and reduced incentives for farmers to increase production and for private operators to invest in other value chain segments, resulting in long periods of agricultural stagnation or contraction.

Table 2.4 presents common features of agricultural marketing policies during the 1960s, 1970s, and 1980s in Africa. We list only a few country examples, but most of these policies were very widespread; for example, the Food and Agriculture Organization of the United Nations (FAO) identified more than 100 marketing boards for various crops in African countries in 1981 (Jones 1987).

African countries were not unique in discriminating against agriculture. Krueger, Schiff, and Valdés (1988) examined agricultural and macroeconomic policies in 18 countries to estimate direct effect on agricultural producer prices resulting from agricultural pricing policies and export restrictions, as well as indirect effects resulting from exchange rate policies and protection afforded to industry. They found that most developing countries discriminated against export crops on both a direct and an indirect basis, resulting in large disincentives for producers. Import-competing food crops were often protected on a direct basis, but the larger negative indirect effects disadvantaged food crop producers as well. For example, in Côte d'Ivoire during the late 1970s, the combined direct effects of agricultural policies and indirect effects of trade policies and industry protection are estimated to have reduced producer prices by 25 percent for rice, an import-competing crop, and by 64 percent for the major export crop, cocoa.

These policies took different forms in different countries. In some countries, revenues from oil, mining, and other natural resource exports exacerbated the exchange rate appreciation and flow of resources out of agriculture (Oyejide 1986; Tshibaka 1986). In several eastern and southern African countries, the implicit taxation of agriculture through overvalued exchange rates was counterbalanced by strong direct support in the form of input and other subsidies, as well as investments in research and extension (Jayne and Jones 1997). However, this support was coupled with tight control of crop marketing and processing, which harmed consumers and stifled investments.

\section{Policy Reforms and Lessons}

Ultimately, ISI strategies and associated agricultural policies were both unsuccessful and unsustainable on budgetary grounds. By the early 1970s, the limits of industry-biased strategies were becoming apparent as manufacturing failed to take off and agriculture sectors atrophied. African leaders embarked on a succession of strategies that shifted widely between industry and agriculture as the main driver of development, and between the public and the private sector as the 
TABLE 2.4-COMMON AGRICULTURAL MARKETING POLICIES, AFRICA, 1960s-1980s

\section{Type of policy}

\section{Examples}

Marketing boards with monopoly over purchase, sale, and export of commodities

Malawi: Agricultural Development and Marketing Corporation purchases maize and other crops from smallholders.

Mali: Compagnie Malienne de Développement des Textiles has exclusive right to purchase and market cotton.

Administratively determined

panseasonal and panterritoria

Tanzania: Maize producer prices fixed based on cooperative and National Agricultural Products Board costs.

Malawi: Panterritorial pricing introduced to promote production in remote areas. Maize is subsidized, but cash crops are taxed.

\begin{tabular}{|l|l|}
\hline Restrictions on private trade & $\begin{array}{l}\text { Kenya: Movement of grain between districts illegal except for licensed traders. } \\
\text { Mali: Private trade in cereals banned. }\end{array}$ \\
\hline Restrictions on private processing & $\begin{array}{l}\text { Kenya, Zambia: Small number of large-scale licensed millers have de facto monopoly on processing and } \\
\text { sale of maize meal. }\end{array}$
\end{tabular}

Senegal: State-run plants have monopoly on groundnut processing.

Public provision of inputs

Benin: Parastatal Société Nationale de Promotion Agricole holds monopoly on fertilizer and pesticide distribution; input prices are subsidized.

Ghana: Ministry of Food and Agriculture and parastatals arrange procurement and distribution of

fertilizer at subsidized, panterritorial price

Control of food retail markets and prices

Madagascar: State organizations responsible for rice wholesale and retail: consumer prices subsidized. Senegal: Caisse de Péréquation et de Stabilisation des Prix has monopoly over import, distribution, and sale of foreign rice.

Source: Badiane and Gaye 1999 (Senegal); Badiane et al. 1997 (Benin, Ghana, Madagascar, Senegal); Dembélé and Staatz 1999 (Mali); Jayne and Jones 1997 (Kenya, Tanzania, Malawi).

predominant economic actor. These shifting policies did not allow the required consistency and continuity for their expected objectives to be met.

Incoherent policy paradigms and unceasing experimentation with agricultural development strategies led to slowing growth across African countries throughout the 1970s (see Figure 2.2). The result was worsening budget and foreign exchange deficits, severe debt crises, and declining incomes (Badiane and Makombe 2015). Finally, in efforts to get out of the deep crisis where most countries found themselves after years of unsuccessful strategies, the majority of African countries initiated wide-ranging reform programs as conditions for loans from the International Monetary Fund (IMF) or World Bank. Key conditions included macroeconomic stabilization measures, such as reducing fiscal deficits and reversing overvalued exchange rates, and sectoral policy and institutional changes, such as eliminating agricultural marketing boards, ending subsidies, deregulating agricultural pricing and marketing, and removing restrictions on private sector participation. The rationale for these reforms, known as structural adjustment programs (SAPs), was that greater macroeconomic stability and the removal of barriers and distortions would increase incentives for producers and allow private sector operators to invest in value chains and thus accelerate agricultural and overall economic growth.

The literature on the effects of SAPs is mixed. In particular, early studies carried out within the first decade of the reform agree that the programs did not meet expectations. Przeworski and Vreeland (2000) characterized early findings on the effects of IMF loans on economic growth as inconclusive. Tanzi (1989) argued that IMF stabilization programs focused too exclusively on reduction of fiscal deficits and that often the measures chosen, such as reductions in budgets for education and maintenance of infrastructure, were those with particularly strong growth-reducing effects.

Early studies also found that SAPs had at best ambiguous effects on poverty. Easterly (2003) found that in countries receiving structural adjustment loans, growth was less pro-poor than in other countries. Kherallah and others (2002) pointed out that welfare effects of reforms were complex; whereas some farmers were negatively affected by the removal of input subsidies and other direct support, export crop producers gained from higher prices, and net food buyers benefited from lower food prices due to reductions in marketing margins in many countries. 
The reforms resulted in increased production in some countries and for some crops. Cash crops, which saw improved price incentives, showed the largest increases (Kherallah et al. 2002). In Mali, increased rice producer prices and the introduction of quality premiums led to demand for improved production technologies and dramatically increased rice productivity (Dembélé and Staatz 1999). However, in some countries, production decreased due to the withdrawal of previous government support (Jayne and Jones 1997).

In many countries, the production response was hampered by hitherto suppressed and thus underdeveloped input and output markets. One important lesson from the reform experience is that developing efficient markets in such a context was not as simple as withdrawing government involvement. Indeed, despite improvements in market functioning, private operators were not able to quickly fill the gaps in marketing after years of restrictions and underinvestment (Jayne et al. 2002; Kherallah et al. 2002). Market liberalization did give rise to competitive private markets for farm outputs, with extensive entry of small-scale traders in most countries. However, these small traders were usually unable to significantly expand their operations due to constraints related to transport costs, access to credit, limited experience and skills, and in some cases competition from remaining public marketing boards. Badiane (2000) found that trading costs and market integration improved in Benin and Ghana following reforms, but not in Malawi, where the public marketing agency still played a strong role in maize trade. In Mali, where market liberalization was accompanied by provision of credit and market information services for private operators, the availability of grain in markets increased and margins fell, benefiting both consumers and producers (Dembélé and Staatz 1999).

Overall, the SAP period of the 1980s and 1990s was one of poor economic growth in Africa (see Figure 2.1). However, the effects of reforms are difficult to assess, especially in the early years, simply because reforms did not occur to their full extent. In many countries, reforms were partial or later reversed; in some cases, the government made room for the private sector in agricultural marketing but retained control over the environment in which the private sector operated (Jayne et al. 2002). For example, in Senegal, the government removed some groundnut marketing restrictions but retained panseasonal and panterritorial pricing, and maintained control over groundnut processing (Badiane and Gaye 1999). Anderson (2010) suggested that whereas most developing countries had eliminated or reversed anti-agriculture bias by the late 1990s and early 2000s, these distortions remained in Africa. The countries that implemented reforms most completely and consistently tended to have the most positive effects in terms of market functioning and productivity increases (Badiane 2000; Dembélé and Staatz 1999).

In some cases, reforms occurred but with significantly delayed timelines (Jayne et al. 2002). This reflects findings in later studies suggesting that reforms associated with SAPs did eventually contribute to macroeconomic stabilization and ultimately to the growth recovery, which began around 2000 (Badiane et al. 2015). Many countries made significant progress in improving the macroeconomic environment between the mid-1990s and mid-2000s (Devarajan and Shetty 2010). Several studies using data through the mid-2000s found that reforms associated with the SAPs made important contributions to agricultural productivity growth (Fuglie and Rada 2013; Yu and Nin-Pratt 2011; Block 2010). It therefore appears that policy reforms enacted in the 1980s and 1990s took some time to work through the economic systems and yield the anticipated effects on growth and development outcomes, in addition to the effects of continued reforms into the 2000s. The trajectory of agriculture-sector and economic growth in the 25-year period that followed the reform decades is a strong proof of the value of appropriate and effectively implemented national economic policies. In the next section, we attempt to quantify the role of policy factors in explaining economic trends through econometric analysis. Following that, we examine policy developments during the postrecovery period that succeeded the SAPs.

\section{Policy Changes and Economic Recovery: Empirical Evidence}

The economic and agricultural dynamics reviewed in the first section of this chapter have much to do with the policy changes discussed in the second section. However, economic outcomes have multiple causes in addition to policy. In this section, we test empirically how a wide range of policy instruments determine growth outcomes in Africa. To do so, we estimate a convergence model à la Barro and Sala-i-Martin (1990). The concept of macroeconomic convergence is based on the Solow growth model, which predicts that two countries with the same levels of certain parameters-savings rates, population growth rates, rates of technical progress, and so on-must ultimately exhibit similar levels of per capita income, irrespective of the initial state of each of these economies. On the relevance of the convergence model in assessing the impact of policies, Sachs 


\begin{tabular}{|c|c|c|}
\hline Type of model & Unconditional convergence & Conditional convergence \\
\hline Nonspatial & $\begin{array}{l}\frac{1}{T} \ln \left(\frac{p_{i t}}{p_{i 0}}\right)=\alpha+\beta \ln \left(p_{i 0}\right)+\mu_{i}+\varepsilon_{i}, \\
\text { where } p_{i t} \text { is per capita GDP, } \mu_{i} \text { denotes } \\
\text { country-specific effect, } T \text { is the length } \\
\text { of time under consideration, and } \\
\varepsilon_{i} \sim \operatorname{iid}\left(0, \delta_{\varepsilon}^{2}\right) .\end{array}$ & $\begin{array}{l}\frac{1}{T} \ln \left(\frac{p_{i t}}{p_{i 0}}\right)=\alpha+\beta \ln \left(p_{i 0}\right)+\gamma X_{i t}+\mu_{i}+ \\
\varepsilon_{i}, \\
\text { where } X_{i t} \text { represents the set of policy } \\
\text { variables for country in period } t .\end{array}$ \\
\hline
\end{tabular}

and Warner argued that membership in the "convergence club" is better defined according to policy choices than initial levels of human capital, concluding that "convergent growth can be achieved by all or virtually all countries that follow a reasonable set of political and economic policies, including civil peace, basic adherence to political and civil rights, and an open economy, through the absence of trade quotas, export monopolies, or inconvertible currencies" $(1995,13)$.

Table 2.5 provides the specifications of the convergence model. Under unconditional convergence, per capita GDP growth is faster in countries with lower initial per capita GDP levels. Under conditional convergence, growth depends not only on initial per capita GDP levels but also on a set of policy variables that literature suggests have an impact on growth. If the two specifications (conditional and unconditional) are equivalent, meaning that jointly added instruments are statistically nonsignificant, then difference in per capita income is solely driven by the initial state. The use of a generalized mixed linear model (which combines fixed and random effects) using panel data not only offers protection against bias arising from reverse causality under a wide range of conditions but also helps to circumvent the problem of misspecified temporal lags (Leszczensky and Wolbring 2019).

We test for unconditional and conditional convergence using per capita GDP growth and other economic data from 54 African countries for the period 1995-2015, taking into account a number of policy variables-including measures of agricultural sector support, macroeconomic management, and governance-that are likely to affect economic growth. Overall, for each specification, our findings confirm the importance of policy instruments in driving economic recovery. One key variable is the relative rate of assistance, or RRA (see Anderson et al. 2008 for estimation methods), which compares the rate of government assistance in agriculture with the rate of assistance in the rest of the economy. The RRA represents the combined effects of sectoral and macroeconomic policies. Positive RRA values indicate that agriculture is protected relative to other sectors, whereas negative values indicate discrimination against agriculture, such as that practiced in many African countries prior to reforms. RRA captures the anti-agricultural bias in a true general equilibrium framework, where economic agents have to decide in which activity they will work and invest (Baliño et al. 2019). In addition to favorable agricultural policy, proxied by the RRA, we allow for a wide range of policy instruments, including macroeconomic stabilization and governance indicators, as major determinants of overall growth recovery. External factors such as official development aid (ODA) and emerging relations with China are also taken into consideration. We also include health and education variables to account for the effects of human capital.

We report expected per capita GDP for each combination of policy instruments in Figure 2.4 and estimation results in Table 2.6. Overall, we could not find evidence of unconditional convergence; ${ }^{2}$ as in Badiane and others (2015), it is only when policy instruments are included in the model that we observe evidence of significant growth convergence. In other words, countries with lower initial levels of per capita GDP are growing faster than those with higher initial per capita GDP, conditional on their policy choices. The negative correlation between initial per capita income levels and subsequent growth in per capita income is in line with the findings of Abramovitz (1986), Baumol (1986), and Barro and Sala-i-Martin (1990). Below we discuss the effect of each relevant policy instrument.

In our estimation, increased assistance to the agricultural sector compared with other sectors, as represented by the RRA, is expected to increase per capita GDP growth, although its significance disappears when coupled with the variables on quality of institutions, foreign aid, and macroeconomic and human

2 There is evidence of convergence if and only if the coefficient associated with the initial value of per capita GDP is significant and negative. 
capital. Moreover, there is evidence of economic convergence whenever the RRA is significant. As pointed out by Baliño and colleagues (2019), prior to the 1980s, developing economies tended to tax their domestic agricultural sectors, whereas advanced economies subsidized their farmers. However, this pattern started to shift in the 1980s, as structural adjustment policies in developing economies ended many of the de facto taxes on agriculture as well as the subsidies that had favored industry (Tsakok 2011; Anderson and Valdés 2008).

Although other literature has found mixed effects from rising exports to China in response to booming demand (Busse, Erdogan, and Mühlen 2016; Zhang, Alon, and Chen 2014; Edwards and Jenkins 2014; Drummond and Liu 2015), in our estimation growth in exports to China contributes positively to economic growth. Overall, foreign direct investments from China are also boosting African economies, although concerns have been raised regarding the allegedly deplorable social conditions of domestic workers involved in China-funded projects (Nnanna 2015; Khodeir 2016).

Both types of ODA-for social infrastructure and services (ODA 100) and for production sectors (ODA 300) - have significant and positive effects on growth. This result is in line with that of Clemens and others (2012), who found that aid does have a modest positive effect on growth on average, although effects differ by country.

The two variables capturing human capital-life expectancy and average years of schooling - positively affected growth among African countries. This reflects evidence from the literature suggesting that one of the most important factors of economic growth is human capital (Lucas 1988; Mankiw, Romer, and Weil 1992), especially with regard to its impact on production through labor productivity (Romer 1990) and promotion of innovation and technology diffusion (Siggel 2000, 2001; Horwitz 2005).
Regarding the quality of institutions, our estimation includes five measures from the World Bank's Worldwide Governance Indicators: (1) voice and accountability, (2) government effectiveness, (3) regulatory quality, (4) rule of law, and (5) control of corruption. We also include the measure of transparency, accountability, and corruption in the public sector from the World Bank's Country Policy and Institutional Assessment. Our results suggest that the most impactful governance and institutions measures are government effectiveness and regulatory quality. Government effectiveness represents "perceptions of the quality of public services, the quality of the civil service and the degree of its independence from political pressures, the quality of policy formulation and implementation, and the credibility of the government's commitment to such policies"; regulatory quality covers the "perceptions of the ability of the government to formulate and implement sound policies and regulations that permit and promote private sector development" (Kaufmann, Kraay, and Mastruzzi 2010, 4). 


\begin{tabular}{|c|c|c|c|c|c|c|c|}
\hline Variable & (1) & (2) & (3) & (4) & (5) & (6) & (7) \\
\hline Initial per capita GDP (1995) & $\begin{array}{l}-0.00135 \\
-0.00202\end{array}$ & $\begin{array}{l}-0.00426^{* *} \\
-0.00174\end{array}$ & $\begin{array}{l}-0.0115^{* * *} \\
-0.00414\end{array}$ & $\begin{array}{l}-0.00343^{*} \\
-0.002\end{array}$ & $\begin{array}{l}-0.00126 \\
-0.00197\end{array}$ & $\begin{array}{l}-0.0111^{* * *} \\
-0.00278\end{array}$ & $\begin{array}{l}0.00491^{* * *} \\
-0.00169\end{array}$ \\
\hline Agricultural relative rate of assistance & & $\begin{array}{l}0.00446^{* *} \\
-0.00201\end{array}$ & $\begin{array}{r}0.00138 \\
-0.00163\end{array}$ & $\begin{array}{l}0.00139 \\
-0.0011\end{array}$ & $\begin{array}{r}0.00081 \\
-0.00171\end{array}$ & $\begin{array}{r}0.00139 \\
-0.00134\end{array}$ & $\begin{array}{l}0.00439 * * \\
-0.00197\end{array}$ \\
\hline Voice and accountability & & & $\begin{array}{l}-0.00442 \\
-0.00295\end{array}$ & & & & \\
\hline Government effectiveness & & & $\begin{array}{l}0.00821^{* *} \\
-0.00379 \\
\end{array}$ & & & & \\
\hline Regulatory quality & & & $\begin{array}{l}0.00677^{* *} \\
-0.00327\end{array}$ & & & & \\
\hline Rule of law & & & $\begin{array}{r}0.00178 \\
-0.00404 \\
\end{array}$ & & & & \\
\hline Control of corruption & & & $\begin{array}{l}-0.00266 \\
-0.00276 \\
\end{array}$ & & & & \\
\hline Transparency, accountability, and corruption (CPIA) & & & $\begin{array}{l}0.000289 \\
-0.00161\end{array}$ & & & & \\
\hline Social infrastructure and services (ODA 100) & & & & $\begin{array}{l}0.0155^{* * *} \\
-0.00122\end{array}$ & & & \\
\hline Production sectors (ODA 300) & & & & $\begin{array}{c}0.0123^{* *} \\
-0.00533\end{array}$ & & & \\
\hline Savings as share of GDP & & & & & $\begin{array}{l}0.942^{* * *} \\
-0.267\end{array}$ & & \\
\hline Foreign reserves as share of GDP & & & & & $\begin{array}{l}6.54^{-08 * * *} \\
-1.04^{-08}\end{array}$ & & \\
\hline Exchange rate (LCU/USD) & & & & & $\begin{array}{l}5.25^{-06 * * *} \\
-1.55^{-06} \\
\end{array}$ & & \\
\hline Life expectancy & & & & & & $\begin{array}{l}0.000939^{* * *} \\
-7.90^{-05}\end{array}$ & \\
\hline Years of schooling & & & & & & $\begin{array}{l}0.00411^{* * *} \\
-0.000504\end{array}$ & \\
\hline Exports to China & & & & & & & $\begin{array}{l}3.03^{-07 * * * *} \\
-8.74^{-08}\end{array}$ \\
\hline FDI from China & & & & & & & $\begin{array}{l}3.20^{-06 * *} \\
-1.40^{-06} \\
\end{array}$ \\
\hline Intercept & $\begin{array}{r}0.0176 \\
-0.0138\end{array}$ & $\begin{array}{l}0.0349^{* * *} \\
-0.0113\end{array}$ & $\begin{array}{l}0.0882^{* * *} \\
-0.0258\end{array}$ & $\begin{array}{l}0.0232^{*} \\
-0.013\end{array}$ & $\begin{array}{l}0.00772 \\
-0.013\end{array}$ & $\begin{array}{r}0.0105 \\
-0.0185\end{array}$ & $\begin{array}{l}0.0389 * * * \\
-0.0109\end{array}$ \\
\hline Fixed and random effects & YES & YES & YES & YES & YES & YES & YES \\
\hline Wald test (Chi ; p-value) & & & $(25.4 ; 0.00)$ & $(289.5 ; 0.00)$ & $(24.5 ; 0.00)$ & $(334.6 ; 0.00)$ & $(21.1 ; 0.00)$ \\
\hline AIC & $-6,757.1$ & $-2,471.8$ & -867.3 & $-1,505.6$ & $-2,280.3$ & $-2,089.4$ & $-2,483.4$ \\
\hline $\mathrm{BIC}$ & $-6,737.1$ & $-2,452.4$ & -837.4 & $-1,483.1$ & $-2,250.4$ & $-2,064.4$ & $-2,456.3$ \\
\hline ICC & 0.653 & 0.452 & 0.836 & 0.863 & 0.600 & 0.835 & 0.443 \\
\hline Observations & 1,100 & 357 & 112 & 182 & 310 & 265 & 357 \\
\hline Number of groups & 48 & 23 & 16 & 23 & 21 & 18 & 23 \\
\hline \multicolumn{8}{|l|}{ Source: Authors. } \\
\hline $\begin{array}{l}\text { Note: Standard errors in parentheses. }{ }^{* * *} p<0.01, * * p< \\
F D I=\text { foreign direct investment; GDP }=\text { gross domestic } p \\
\text { model specifications capturing the impacts of each grou }\end{array}$ & $\begin{array}{l}\text { 0.1. AIC }=A \\
C=\text { residua } \\
\text { oles. }\end{array}$ & $\begin{array}{l}\text { nation } c r \\
\text { rrelation }\end{array}$ & $\begin{array}{l}=\text { Bayesian } \\
\text { I currency u }\end{array}$ & $\begin{array}{l}\text { criterion; CP } \\
\text { fficial devel }\end{array}$ & $\begin{array}{l}\text { try Policy ar } \\
\text { d; USD = US }\end{array}$ & $\begin{array}{l}\text { nal Assessme } \\
\text { lumns 1-7 shor }\end{array}$ & $\begin{array}{l}\text { e World Bank; } \\
\text { esults of different }\end{array}$ \\
\hline
\end{tabular}


Finally, macroeconomic instruments such as savings, foreign reserves, and exchange rates all have significant and positive impacts on per capita GDP growth. The role of macroeconomic stability on overall economic development has been long established in the literature. Montiel and Servén (2006) argued that fiscal solvency and price stability are conducive to growth because macroeconomic instability hampers investors' ability and willingness to undertake investment opportunities. During the period of robust growth, the World Bank (2006) reported an improvement in the overall macroeconomic environment among African countries, with inflation down to historic lows, exchange rate distortions mostly eliminated, and fiscal deficits declining.

It is clear from the above findings that better sectoral and macroeconomic policies in Africa work the same way as they do in all other economies, boosting growth and overall economic performance. Sustaining and deepening the current recovery process will require a continued improvement of the economic policy environment in African countries. More important, as these economies transform, there is a call for an adjustment and refinement of policy regimes in order to respond effectively to emerging opportunities and challenges. In the next section, we review past efforts to renew policy regimes in Africa's agricultural sectors for lessons to guide future efforts to shape the best policy environment for agricultural and economic growth and enhanced prosperity.

\section{Policy Renewal in Africa's Agricultural Sector}

\section{Agricultural Policy Directions from the Lagos Plan of} Action to NEPAD

In 1980, the Organisation of African Unity (OAU) issued the Lagos Plan of Action 1980-2000 (LPA), a first attempt by African leaders to put in place a continentwide development framework owned and led by Africans. The LPA acknowledged that "rather than result in an improvement in the economic situation of the continent, successive strategies have made it stagnate" (OAU 1980,4) and noted the urgent need for countries to place a higher priority on agriculture. However, the LPA was more a political document than an action plan, and it largely lacked actionable targets for the agricultural sector and other monitoring and evaluation provisions (Conway, Badiane, and Glatzel 2019; UNECA 1991). Despite good intentions, the LPA was not implemented as intended and the next decade and a half were dominated by the SAPs.
Two decades later, increased skepticism about external development agendas and the advent of a new generation of leaders with pan-African visions paved the way for a more successful attempt to put in place an African-driven development agenda for the continent. During the late 1990s and early 2000s, just as economic and agricultural growth were beginning to rebound, a series of new continental strategy initiatives ultimately formed the basis for the establishment of the New Partnership for Africa's Development (NEPAD), which was adopted in 2001 by the OAU and in 2002 by the OAU's successor, the African Union (Conway, Badiane, and Glatzel 2019).

NEPAD provided a blueprint for a new type of relationship between Africa and the global community. It expressed the need for development partners to coordinate their support and align it with African countries' own priorities and programs, and emphasized the importance of accountability on the part of both donors and recipient countries. NEPAD also called upon African leaders to improve governance and management for better development outcomes. NEPAD values include inclusivity and participation, with multiple stakeholder groups having a role to play in policy formulation and implementation, as well as accountability and review (Conway, Badiane, and Glatzel 2019).

\section{Content, Values, and Principles of CAADP as a New}

Policy Framework

The Comprehensive Africa Agriculture Development Programme (CAADP) was launched in 2003 as NEPAD's main agricultural development initiative. In adopting CAADP, African leaders committed to two key targets-allocating 10 percent of public expenditures to agriculture and achieving a 6 percent average annual agricultural growth rate-as well as to the principles and values of inclusivity, accountability, and review. CAADP also emphasizes the importance of evidence-based agricultural policymaking, including monitoring and evaluating progress and impacts.

The first decade of CAADP implementation culminated with the signing in 2014 of the Malabo Declaration on Accelerated Agricultural Growth and Transformation for Shared Prosperity and Improved Livelihoods. In the declaration, leaders recommitted to the principles and values of CAADP and to the 10 percent agricultural expenditure share and 6 percent agricultural growth targets. In recognition of the strong relationship between agricultural and overall development, they also expanded the CAADP agenda significantly, 
incorporating additional goals and commitments to be achieved by 2025 , including halving poverty and ending hunger, tripling the level of intraAfrican agricultural trade, and enhancing resilience to climate and other risks, among others. The Malabo Declaration also called for a continentwide accountability and review platform to track and report on progress in meeting agricultural development goals. In response, the first biennial review (BR) was held in 2017 and the second in 2019 , with participation from nearly all African countries.

\section{Contribution, Impact, and Limits of Policy Renewal under CAADP}

CAADP has made significant qualitative contributions to the agricultural policymaking environment in Africa. First and foremost, CAADP has raised the profile and increased the prioritization of agriculture in African and global policy agendas. CAADP's realization of mutual accountability has been recognized as a best practice internationally, with key CAADP processes emulated in other continents. For example, the Global Agriculture and Food Security Program, a multidonor agricultural financing platform, requires African countries applying for funding in support of agriculture and food security strategies to have completed a CAADP National Agriculture Investment Plan. Non-African countries must have completed and reviewed an investment plan through a CAADP-like process. Importantly, CAADP has contributed to advancing a culture of evidence-based policymaking in Africa (Badiane, Benin, and Makombe 2016).

CAADP has also provided quantitative benefits for agricultural development goals. Figure 2.5 compares agricultural growth and expenditure outcomes for the countries that are most advanced in CAADP implementation, referred to as CAADP 4 countries, and those that have not engaged with CAADP, known as CAADP 0 countries. The CAADP 4 countries have had stronger agricultural growth and maintained higher agricultural expenditure shares than those not engaged with CAADP. These development outcomes result from numerous drivers, and the trends shown in Figure 2.5 merely suggest correlations between CAADP status and outcomes. However, more rigorous statistical impact analysis by Benin (2018) has shown that CAADP allowed the countries most advanced in implementation to raise land and labor productivity and increase government agricultural expenditure as well as development aid for agriculture. 
However, there have been limits to CAADP's ability to sustain increased investments for agricultural growth and productivity. Undoubtedly the rising prominence of agriculture on continental and national policy agendas enabled some countries to significantly raise funding to the sector. In some cases, however, the bulk of increased expenditures have gone toward input subsidies, rather than investments for long-term productivity growth such as research and development. The majority of countries have fallen short of the CAADP 10 percent agricultural budget allocation target: whereas 12 countries met or surpassed the target in at least one year during the 2014-2018 period, the average expenditure share for the continent as a whole was just 3.2 percent. The 6 percent agricultural growth target has also remained out of reach of the majority of countries, although 15 countries met the goal during the 2014-2018 period.

Overall, nearly all countries had made positive progress toward the Malabo goals and targets between the 2017 and 2019 BRs, but most were not considered on track to meet the goals by 2025 (Makombe and Kurtz 2020). CAADP has made significant achievements in increasing the practice of evidence-based policymaking in the agricultural sector. However, Africa is not immune to a return to failed policies of the past. It is therefore important to build on the achievements of CAADP and pursue efforts to further raise the quality of agricultural-sector and economic policy regimes. Any attempt to roll back the progress toward policy renewal launched under CAADP will risk jeopardizing the ongoing economic recovery process.

\section{The Risk of Policy Reversal and Its Avoidance}

\section{Risk Factors and Signs of Policy Reversal}

Unlike the SAPs, which were focused on the adoption of specific policy instruments, CAADP seeks to improve the overall quality of policymaking by ensuring that policies are evidence-based and subject to inclusive review. Where mutual accountability processes are weakened and where policy is driven by populism rather than evidence of impact, countries will become more susceptible to repeating the strategies that resulted in economic stagnation in previous decades. African countries experience a remarkably better situation today than they did at the turn of the millennium, in terms of stronger growth and increased incomes. However, the recovery and other positive developments also present a very real risk of policy reversal. Stronger fiscal positions and more open and pluralistic political systems, though they are welcome changes, also raise the risk that politicians will succumb to populist pressures to prioritize short-term gains over longer-term growth. A new generation of leaders, a lack of institutional memory, and lingering mistrust of markets increase the chances that government may try to dictate economic activities to an unsustainable degree.

The risk of returning to the types of policies that stifled the agricultural sector and posed barriers to farmers is demonstrated by the rising tendency in many countries to resort to price controls and export bans in an effort to ensure food security, and to rely on input subsidies and public agricultural agencies to support agricultural development. There have been examples of temporary policy reversals in the past in response to crises, such as the protectionist trade policies implemented during the 2007/2008 food price spike (Deason et al. 2014); the policy reversals seen today have more disparate drivers and risk becoming long-term if they are not reversed quickly. Table 2.7 lists examples of agricultural policies proposed or implemented in late 2018 and 2019 alone that indicate the propensity to return to centrally administered agricultural marketing strategies.

Over the period shown in Table 2.7, several countries instituted import bans or put in place import restrictions, usually to protect local producers or industries. For example, Burundi imposed a ban on fertilizer imports in August 2019 in order to promote the development of a Burundian organo-mineral fertilizer plant (AfricaFertilizer.org 2019); Nigeria tightened restrictions on foreign exchange for food importers in the same month, and in October 2019 issued a complete ban on imports via land borders. Other countries instituted export bans or price controls to support food security. In October 2018, Zambia temporarily banned exports of maize and maize meal following lower-than-average production; Zambia's periodic export bans are estimated to have cost the country US $\$ 1.4$ billion in revenue during the 2008-2016 period (Chisanga, Subakanya, and Makungwe 2018).

In other cases, governments took control over key aspects of crop markets. In Uganda, the Ministry of Agriculture set dates for the June and December 2019 vanilla harvests in an effort to improve the quality of vanilla by preventing harvest of immature beans. Harvesting vanilla outside of the set dates was punishable by law; adjusting the dates based on local weather patterns required approval from the ministry (Christopher 2019). In Tanzania, the government banned private traders from purchasing cashew nuts from growers in November 
2018 on the grounds that the prices offered were too low, and instead bought the entire cashew crop itself. The Ministry of Trade and Industry was still searching for buyers in February 2019 (The Citizen 2018; Alfa Shaban 2019).

\section{TABLE 2.7-SELECTED AGRICULTURAL POLICIES, OCTOBER 2018-OCTOBER 2019}

\begin{tabular}{|c|c|c|c|c|}
\hline Country & Date & Policy & Objective & Source \\
\hline Benin & March 2019 & $\begin{array}{l}\text { Cashew marketing } \\
\text { order setting a } \\
\text { minimum price for } \\
\text { cashew nuts }\end{array}$ & $\begin{array}{l}\text { Ensure profits for } \\
\text { producers and } \\
\text { affordable materials } \\
\text { for processors }\end{array}$ & $\begin{array}{l}\text { Republic of } \\
\text { Benin } 2019\end{array}$ \\
\hline Burundi & August 2019 & $\begin{array}{l}\text { Ban on fertilizer } \\
\text { imports }\end{array}$ & $\begin{array}{l}\text { Protect new local } \\
\text { fertilizer factory }\end{array}$ & $\begin{array}{l}\text { AfricaFertilizer. } \\
\text { org } 2019\end{array}$ \\
\hline Kenya & March 2019 & $\begin{array}{l}\text { Draft regulations to set } \\
\text { food prices }\end{array}$ & $\begin{array}{l}\text { Protect consumers } \\
\text { from high prices }\end{array}$ & $\begin{array}{l}\text { Food Business } \\
\text { Africa.com } 2019\end{array}$ \\
\hline Nigeria & August 2019 & $\begin{array}{l}\text { Expansion of ban on } \\
\text { provision of foreign } \\
\text { exchange by the } \\
\text { Central Bank to food } \\
\text { importers }\end{array}$ & $\begin{array}{l}\text { Protect local food } \\
\text { producers }\end{array}$ & $\begin{array}{l}\text { Awoyinfa, } \\
\text { Chiedozie and } \\
\text { Okon } 2019\end{array}$ \\
\hline Nigeria & October 2019 & $\begin{array}{l}\text { Complete ban on } \\
\text { imports through land } \\
\text { borders }\end{array}$ & Combat smuggling & $\begin{array}{l}\text { Sahara Reporters } \\
\text { New York } 2019\end{array}$ \\
\hline Tanzania & $\begin{array}{l}\text { November } \\
2018\end{array}$ & $\begin{array}{l}\text { Ban on private } \\
\text { traders buying } \\
\text { cashew nuts from } \\
\text { farmers; institution of } \\
\text { government buying }\end{array}$ & $\begin{array}{l}\text { Provide higher prices } \\
\text { for farmers; eliminate } \\
\text { role of middlemen }\end{array}$ & The Citizen 2018 \\
\hline Uganda & May 2019 & $\begin{array}{l}\text { Administrative setting } \\
\text { of vanilla harvest dates }\end{array}$ & $\begin{array}{l}\text { Improve vanilla quality } \\
\text { by preventing harvest } \\
\text { of immature beans }\end{array}$ & $\begin{array}{l}\text { Christopher } \\
2019\end{array}$ \\
\hline Zambia & October 2018 & $\begin{array}{l}\text { Export ban for maize } \\
\text { and maize meal }\end{array}$ & $\begin{array}{l}\text { Promote food security; } \\
\text { build strategic } \\
\text { reserves }\end{array}$ & $\begin{array}{l}\text { Lusaka Times } \\
2018\end{array}$ \\
\hline
\end{tabular}

\section{Avoidance Strategies}

Governments face immense pressure to take action to address issues of food security and producer incomes in the short term. How, then, can countries avoid repeating the mistakes of the past? Many of the misguided development policies of the past were intuitively appealing as well as promoted by development theorists (see, for example, Prebisch 1950; Singer 1950). However, they were largely uninformed by empirical evidence. If policymakers had acted based on evidence of what had worked in similar contexts, they may have avoided some missteps; if impacts had been monitored carefully, the most harmful policies could have been reversed before inflicting so much damage. The best guard against repeating past mistakes is to ensure that evidence is brought to bear at every stage of policy formulation, implementation, and review, and that policies are subject to revision based on evidence of impact. Several mutually reinforcing elements are required to ensure a supportive environment for evidence-based policymaking. These include robust data systems that rely on local expertise to collect and analyze data; coordination and knowledge management functions to link data generators and users, and ensure that data and knowledge products are available to all; and mutual accountability platforms to put knowledge to work in assessing policy.

Mutual accountability, the process through which different actors hold each other accountable for their commitments to actions and results, is an important CAADP value, as emphasized in the 2014 Malabo Declaration. Mutual accountability in the agricultural sector is put into practice at the continental level through the BR process and at the country level through joint sector reviews (JSRs). JSRs are generally annual events organized by government ministries of agriculture and other relevant ministries and departments, in collaboration with representatives from the private sector, farmers' organizations, civil society organizations, and donors. They provide an opportunity for participants to review progress in the agricultural sector and the status of commitments made by different stakeholder groups, as well as participate in joint planning and prioritization. JSRs are informed by studies on selected topics, which are carried out before the JSR meeting. As of September 2019, 31 African countries had conducted or initiated an assessment of their agricultural review processes in order to improve their adherence to JSR best practices (Makombe, Tefera, and Ulimwengu 2019).

Likewise, the BR at the continental level offers an opportunity for leaders to be held accountable among their peers and their own constituents to the commitments made at the launch of CAADP in 2003 and with the Malabo Declaration of 2014. Each country's performance on the BR indicators highlights the areas that need to be prioritized to accelerate progress toward achieving the CAADP and Malabo goals. 
Accountability platforms such as the JSR and BR are important for several reasons. First, they provide an essential opportunity for policies to be scrutinized, assessed, and potentially revised, based on perspectives from different groups that the policies affect in distinct ways. For example, Malawi's JSR offered an opportunity for nonstate actors to voice concerns about the country's input subsidy program, which led to reforms to make the program more private sector-friendly (Makombe and Collins 2018). In addition, regular and robust accountability platforms build a culture of review and ensure sustained demand for evidence and knowledge, reinforcing the development of country data and knowledge management systems.

\section{Future Policy Options for Transforming African Economies}

The power of national policies to affect living conditions cannot be overstated, as demonstrated by Africa's experience of economic decline and recovery in the decades since independence. Getting policies right is not easy-both long-term development goals and the pressure to respond to short-term needs can lead policymakers to adopt ineffective or harmful strategies. Leaders can draw lessons from previous decades on the importance of sound macroeconomic management and the elimination of distortionary sectoral policies. However, there will always be new challenges and opportunities that will require new responses, and a conducive policymaking environment is essential to help policymakers both avoid repeating past mistakes and ensure that new missteps are quickly recognized and addressed. New developments in Africa requiring innovative responses include rising opportunities for local agro-industries and risks from climate change and other shocks. In particular, novel shocks such as the COVID-19 pandemic that struck in 2020 further heighten the risk of policy reversal as countries take rapid actions to protect health and food security, sometimes pursuing policies that may prove counterproductive (for example, see Resnick 2020; Bouët and Laborde 2020). Evidence-based policymaking and rigorous and inclusive review as promoted under CAADP are essential to respond adequately to these new challenges. Key emerging areas that policymakers need to address in the short term include agro-industrial policy, technology and innovation strategy, and social protection systems. We discuss each of these areas in turn.
Agro-industrial Policy

Africa's more affluent, urbanizing population is contributing to rapidly rising demand for food overall, and especially for higher-value perishable and processed foods. These developments present a major opportunity for domestic producers, if they are able to connect with urban markets. A subsector of micro and small firms has sprung up to process local staples and market them to urban consumers (Reardon 2015), but these firms face daunting constraints that largely prevent them from growing and increasing production and employment. These constraints include lack of energy, infrastructure, and skills and knowledge, and unstable access to the raw materials required (Hollinger and Staatz 2015).

Action to facilitate development of the emerging agro-processing sector is important both to capitalize on the potential of the large informal sector to contribute more strongly to economic growth, and to allow farmers to realize the benefits from increased productivity by connecting with urban consumers. At this stage governments should focus on improving transport, market, energy, and communications infrastructure in order to lower firms' operating costs, and on increasing access to skills and knowledge through vocational training, particularly on management practices. As firms mature and grow, policymakers should pursue strategies including industrial zones with high-quality infrastructure, transfer of knowledge from abroad, access to credit, and an enabling regulatory environment, including protection of intellectual property (Sonobe and Otsuka 2011; Badiane and McMillan 2015).

\section{Technology and Innovation Policy}

Technology and innovation policy is an important element of support to agroindustries as well as efforts to accelerate broader economic development. An enabling environment for technology development and adoption starts with enhancing national agriculture research systems (NARS), which are too often underfunded as well as poorly coordinated both internally and with counterparts in other countries (Roseboom and Flaherty 2016). Policymakers should facilitate strategic connections between public sector research and development institutions and the private sector so as to constitute a single innovation ecosystem, with the public and private sectors playing complementary roles in developing, scaling up, and disseminating innovations (Badiane and Collins 2020). Skills development and upgrading is required at all levels, from farmers to policymakers to the 
youth who will constitute the next generation of innovators. Areas of particular need are agricultural extension services, agricultural technical and vocational education and training programs, and undergraduate and graduate programs in agricultural sciences. Skills development initiatives and NARS should place a high priority on new and emerging technologies, including biotechnology and digital technologies, both of which have the potential to significantly increase agricultural productivity.

Technologies to generate and deliver energy are also urgently needed. Africa faces the highest costs of electricity provision in the world, and large shares of the population, particularly in rural areas, remain unconnected to energy grids. Policymakers should explore promising off-grid and mini-grid solutions that could meet the needs of farmers, agro-industries, and households in remote areas (Malabo Montpellier Panel 2019).

\section{Productive Social Protection Policies}

Climate change represents a wide-ranging and severe challenge to African agriculture, and threatens recent progress in increasing productivity and reducing poverty and hunger. A range of policy responses will be required to address the effects of climate change on production and livelihoods. ${ }^{3}$ One key intervention will be the scaling up of social protection programs, which are vitally important to protect assets in the face of climate-related and other shocks. The effects of the COVID-19 pandemic on employment and poverty, both in Africa and across the world, have underlined the importance of safety nets to ensure well-being in the face of unexpected crises. Social protection policies also ensure that growth is inclusive by supporting the welfare of populations otherwise left behind.

Program design should be based on careful reviews of evidence from effective programs in similar contexts, and must be subject to review and revision (Berhane and Hirvonen 2018). The objectives of social protection programs should be coherent with other development goals, including strategies in the agricultural sector. Social protection programs that contribute to increasing agricultural labor productivity are especially effective at helping to reduce poverty in the longer term (Makombe, Tefera, and Benin 2018).

\section{Way Forward}

Africa's experience has shown that the quality of policymaking has serious consequences for people's welfare and livelihoods. After decades spent searching for successful policies, during which standards of living declined and poverty rose, Africa has finally begun to realize the potential of its agriculture sector. Policy renewal efforts, increasing prioritization of agriculture, and recognition of the importance of evidence to inform policies have improved the quality of policymaking and led to economic and agricultural recovery. However, there are alarming signs that some African countries are increasingly returning to policies that show unsustainable levels of public control over agricultural sector operations. At the same time, policymakers are called upon to respond to new and emerging issues and opportunities. The best tools to ensure that policies not only avoid past mistakes but also overcome new challenges are a renewed focus on the use of evidence to inform policies and the practice of accountability and review to assess policy effectiveness.

\footnotetext{
3 Evidence on climate-smart agriculture policies and practices is summarized in De Pinto and Ulimwengu (2017)
} 